\section{BIOLOGY OF THE ANTARCTIC SEAS}

Biology of the Antarctic Seas

Edited by Milton O. Lee. (Antarctic Research Series, Vol. 1.) Pp. ix +186 . (Washington, D.C.: American Geophysical Union of the National Academy of Sciences -National Research Council, 1964.) 10 dollars.

$\mathrm{F}^{\mathrm{I}}$ VE of the eight papers presented here are devoted to experimental biology, with contributions from J. S. Bunt, E. Z. El-Sayed, E. F. Mandelli and Y. Sugimura on primary organic production, D. E. Wohlschlag on the respiratory metabolism and ecology of some Antarctic fishes, and M. A. McWhinnie on temperature responses and tissue respiration in Antarctic crustacea, with special emphasis on the whale food, or krill, Euphansia superba Dana. Such investigations are fundamental to our understanding of the biology of the Antarctic seas, and it is hoped that many more of them will shortly follow from the laboratories that now girdle the continent. This does not, of course, imply that future research can now be left entirely to the experimenter ashore. For there is still much to do in the field, especially on tho little-known floor of the wide circum-polar abyssal sea.

M. A. McWhinnie's examinations on live krill in U.S.N.S. Eltanin will interest all who have studied these animals from preserved specimens. He finds them, for example, most active and showing the lowest apparent mortality at temperatures of $0^{\circ} \mathrm{C}$ and below. The greatest activity, in fact, was seen at $-1.5^{\circ} \mathrm{C}$, the lowest temperature observed. This is perhaps to be expected, because a very large part of this vast circum-polar population, it has recently been shown, does exist for the greater part of the year at surface temperatures falling within this range.

At South Georgia, it is true, E. superba has been recorded commonly enough up to about $3 \cdot 9^{\circ} \mathrm{C}$, but this occurs only in summer, February-the warmest month. In warmer water it occurs only as a rare straggler. Once or twice it has been recorded just north of the Antarctic convergence, but its occurrence there is anomalous and can be attributed to vagaries in the Antarctic surface current in which it spends so much of its existence. In the Eltanin experiments, $4^{\circ} \mathrm{C}$ proved lethal within $24 \mathrm{~h}$. Euphausians as a whole are notoriously difficult to keep alive, and Dr. McWhinnie is to be congratulated on maintaining some dozens of his specimens for nine days, and five for thirteen days.

I was particularly interested in Robert Menzies's account of the latest techniques for deep-sea trawling used in U.S.N.S. Eltanin. These methods, notably in so far as they permit a fairly accurate determination of duration of contact with the bottom, and a useful estimation of the length of warp required, will doubtless bo used with advantage on deep south polar bottoms, if they are not in fact already in use. But there is no mention of the Antarctic in this paper, the work described having been done in the tropics between Panama and Valparaiso. This is a great pity, as Antarctica has its own special problems, not the least being the cumbering of the sea-bed with erratic stones and boulders dropped by ice breaking away from the continental land. The deep terrigenous ooze so often encountered in these high latitudes presents a further problem, requiring, as I have shown elsewhere ${ }^{2}$, its own technique. Moreover, it has yet to be shown that Menzies's contention, that in the deep sea contact with foul bottom is responsible for only trifling loss of gear, will hold good round the south polar continent. Rocky ground, and especially erratic boulders, can in fact play havoc with trawls and dredges there, especially on the rather deep continental platform. I have seen a large trawl, shot in 1,000 fathoms, torn almost to ribbons, evidently through contact with stony ground. $\mathrm{He}_{\mathrm{e}}$ comments, too, on the exceptionally poor yield of the 'smaller dominant members of the deep sea' by the massive 'Herring Otter Trawl' (HOT) used by the Danes in Galathea. Surely the answer to this is to have fine nets attached to the back of the trawl, which is the technique that was so successfully used in the Antarctic by the late Stanley Kemp and his associates more than thirty years ago.

In "Antarctic Foraminiferal Zonation", O. L. Bandy and R. J. Echols have given an interesting zoogeographical investigation. In high southern latitudes animals so small are prone to 'faunistic displacement', floating icebergs, formerly aground, often being responsible for carrying massive accumulations of bottom material to be deposited eventually in the most unexpected places. The recognition and sorting out of the distributional and bathymetric anomalies that spring from these phenomena are competently handled in this important paper.

Concluding this volume is an exhaustive catalogue and bibliography of the benthic marine algae compiled from a very scattered literature by George A. Papenfuss. It has 240 references going back to 1822 .

J. W. S. MARR

${ }^{1}$ Marr, J. W.IS., Discovery Reports, 32, 33 (1962)

2 Marr, J. W.is., Phil. Trans. B, 246, 327 (1963).

\section{BIRD SONG}

\section{A Study of Bird Sorig}

By Edward A. Armstrong. Pp. $x v+335+16$ plates. (London: Oxford University Press, 1963.) 45s. net.

T $T$ is well known that bird song is much more than a sweet expression of domestic emotion, that it conveys many things, including aggression, courtship, territory ownership and other bits of information important to birds in their social life. Hence, the investigation of the vocalization of birds is being actively pursued by workers in behaviour, communication and systematics, who frequently become recording enthusiasts. In A Study of Bird Song, Armstrong has brought together most of the information accumulated by these workers, and presented it neatly in a condensed and systematic fashion.

The body of the book is mado up of chepters on song structure, its development, the variety of forms and functions of song, and determinants such as light, climate, and the associated breeding cycle. Thero is an introduetory chapter on bird utterances as language, and a concluding one on song as art and play. An appendix surveys acoustic communication in the animal kingdom, and eleven pages of addenda take account of work appearing in two and a half years of delay in publication. There is a thorough bibliography and finally an excollent index with four divisions.

In the treatment of such a broad-ranging subject, no unifying theme is found, and probably none is possible. The first chapter, on bird utterances, directs attention to the wide range of avian vocal signals and their rich content of information. A useful review is included of the sound signal repertoires found in the dozen or so species which have been examined in this respect.

Several chapters on the structure and components of song and on its development summarize much of the information available on this subject at the time of writing. Regarding structure, the emphasis placed on measures of pitch, loudness and quality of bird sounds gives undue importance to these aspects, neglecting the complex intornal structure of the song as a whole, which is revealed in more recent audiospectrographic investigations. In this section there is an illuminating review and discussion of terminology in bird song. A typical suggestion for better usage is the substitution of 'song version' for 'song type' or 'song pattern'. Armstrong rejects, 